\title{
Bespoke Crowdfunding Regulation: A Boost up to Startups and SMEs in India
}

\author{
Rahul J. Nikam \\ Faculty of Law, Marwadi University, India. \\ E-mail: rahul.nikam@marwadiuniversity.edu.in
}

\begin{tabular}{l} 
ARTICLE INFO \\
\hline Keywords: \\
Crowdfunding; \\
Crowd-investment; \\
Equity Crowdfunding; \\
Debt Crowdfunding; \\
Regulation \\
How to cite: \\
Nikam, R.J. (2019). "Bespoke \\
Crowdfunding Regulation: \\
A Boost up to Startups and \\
SMEs in India," Hasanuddin \\
Law Review, 5(1): 55-76 \\
DOI: \\
10.20956/halrev.v5i1.1587 \\
\end{tabular}

\begin{abstract}
The paper reviews securities regulatory requirements across the world and specifically in India that may be applicable or prohibiting Crowdfunding in India. The author argues that Indian financial and securities services regulations were not designed keeping in mind the 21 st century requirements of industry. There is a regulatory gap in recognizing this emerging route of fund-raising business model addressing the needs of start-up as well as the Small and Medium Enterprises (SMEs) businesses by way of crowdfunding and crossborder crowdfunding in the form of equity and debt. Thus, paper is seeking to clarify how crowdfunding fits into existing rules if any and necessity of introducing specific requirements that promote regulatory and supervisory convergence. The aim is to provide appropriate balance of less costly regulatory compliances, prudent risks management for project owners and crowdfunding platforms vis-à-vis raising of funds domestically and through cross-broader. At the same time providing adequate investor protection to the investor who are typically not professional investors.
\end{abstract}

Copyright (C) 2019 HALREV. All rights reserved.

\section{Introduction}

In the recent years, raising of funds for business by entrepreneurs are taking place through extensive usage of internet and social sites networking. Approaching a large number of investors for pooling up of investment or funding through online technology based on crowd is a new financial invention called crowdfunding. This is giving a leveraged opportunity to explore the alternatives of raising an entrepreneurial finance. The other reasons for significant increase in crowdfunding, can be tracked from the 2008 financial crisis that resulted into a steady decline of a various types of credit provider's ability increasingly constrained to lend/investment of money to the real economy. ${ }^{1}$ Also,

Tomczak, A., \& Brem, A. (2013). A conceptualized investment model of crowdfunding. Venture Capital, 15(4), 335-359. 
across the world and specifically in India, the amount of bank loans non-recovery rate is on high ${ }^{2}$ resulting into number of Banks failure. Consequently, application of Capital Adequacy Norms-Basel $\mathrm{III}^{3}$ resulting new stringent regulatory requirements followed by banks making difficult to obtaining loans by start-ups \& SMEs. This liquidity crunch has created a vacuum of funds situation which is boosting up of growing popularity of crowdfunding platforms.

The importance of crowdfunding cannot be undermining, ${ }^{4}$ as it can be seen from last few years IPO market in India 5 is not very active in spite of SEBI's facilitation to the startups and SMEs for fund raising in the form of SME segment in Stock Exchanges6, Category I- SME funds under AIF7, Institutional Trading Platform ${ }^{8}$, etc. Hence, due to aforementioned constraints, there is need for promoting a new innovative fund-raising model that thrust to start-ups/SMEs to raise funds and crowdfunding is one such new financial invention that can help in raising funds9. But, it is also important for regulators across the globe ${ }^{10}$ and SEBI to ensure that there is no systemic risk for retail investors from some unscrupulous players through crowdfunding platforms by substituting the existing framework. ${ }^{11}$ Thus, there is need to strike appropriate balance between recognizing and regulating this emerging route of funding that can support economic development and investor protection. ${ }^{12}$

With these backgrounds, Section 1 of the article briefly explains what is crowdfunding, its types, benefits, role of internet, systemic risk and information asymmetry. Section 2 is a comparative regulatory chart of selected countries on various crowdfunding and cross boarder crowdfunding models. Section 3 is the analysis of existing Indian Acts and regulatory schemes that could be brought to bear upon crowdfunding. This assessment of regulations also looks at various rationales for regulation of public law purposes such as Company Act 2013, SEBI (Start-ups and SME funding) Regulation, SEBI (Alternative Investment Funds (AIFs)) Regulation etc. and review of existing regulatory schemes in India. Chapter 4 discusses proposed regulations on crowdfunding as well as cross-

\footnotetext{
RBI. (2017). Report on Report on Trend and Progress of Banking in India 2016-17. Retrieved form: https://www.rbi.org.in/scripts/PublicationsView.aspx?id=18061

RBI. (2015). Master Circular on Basel III Capital Regulations (Press Release: RBI/2015-16/58 DBR.No.BP.BC.1/21.06.201/2015-16) Retrieved from: $h$ ttps://rbidocs.rbi.org.in/rdocs/content/pdfs/58BS300685FL.pdf

4 World Bank. (2013). Crowdfunding's Potential for the Developing World. Retrieved from: https://www.infodev.org/infodevfiles/wb_crowdfundingreport-v12.pdf

5 SEBI. (2018). SEBI Bulletin- September 2018. Available online at: https://www.sebi.gov.in/sebiweb/home/HomeAction.do? doListing $=$ yes $\mathcal{E}$ sid $=4 \mathcal{E} s$ sid $=30 \mathcal{E}$ smid $=0$

6 SEBI (Framework for recognition and supervision of stock exchanges / platforms of stock exchanges for small and medium enterprises) 2008. Retrieved from: $h t t p: / / w w w . s m e l i s t i n g . n e t / S E B I / S E B I-f r a m e w o r k-f o r-s m e-p l a t f o r m . p d f$

SEBI (Alternative Investment Funds Regulations) 2012. Retrieved from: https://www.sebi.gov.in/sebi_data/commondocs/ AIFregulations2012_p.pdf

8 SEBI (Listing of Specified Securities on Institutional Trading Platform) Regulations, 2013 Retrieved from: https://www.sebi.gov.in/sebi_data/attachdocs/1381311146097.pdf

9 SEBI. 2014 Consultation Paper on Crowdfunding in India. Retrieved from: https://www.sebi.gov.in/sebi_data/ attachdocs/1403005615257.pdf

10 Jumpstart our Business Startups Act, 2012 (United States); Decreto Crescita Bis of December 2012 (Italy); Financial Markets Conduct Bill of September 2013 (New Zealand); Financial Conduct Authority Regulation on equity crowdfunding of March 2014 (UK); Guidance Note on Crowdfunding, Australian Securities and Investments Commission, 12-196MR ASIC guidance on crowd funding, http://asic.gov.au/about-asic/media-centre/find-amedia-release/2012-releases/12-196mr-asic-guidance-on-crowd-funding/

11 Kirby, E., \& Worner, S. (2014). Crowd-funding: An infant industry growing fast. IOSCO, Madrid.

12 Bradford, C. Steven. "Crowdfunding and the federal securities laws. "Colum. Bus. L. Rev. (2012): 1.
} 
border crowdfunding models. In conclusion, offers some principles with the hope that will guide the development of new regulations for governing crowdfunding market in India and customer protection requirements coming out of crowdfunding transactions. The paper is using doctrinal research method by reviewing primarily, law materials in the form of present policies and legislation on share market in India and crowdfunding policies and legislation of selected foreign countries. The secondary date includes outcome of earlier research, journal articles, consultation papers and reports published on crowdfunding.

\section{Crowdfunding: Meaning, Types and Risks}

The term crowdfunding (CF) can be term as the collection of a small portion of amount in a form of fund provided by large number of individuals i.e. crowd to a project/ a business/personal loan with active assistance of online web platform through internet. Community (CCF) and Financial Returns (FRCF) are the two major types of crowdfunding. FRCF can be further sub classified as a Peer-to-Peer (P2P) lending and Equity crowdfunding (ECF). There are various business modules of cross border crowdfunding like separate business operation in foreign country under its local laws, collecting investment by partnering with foreign partner platform in their country, operate as a financial service provider platform under EU license, operate as special purpose vehicles, operate either accepting investment or as a brokering charge on investment by locals in cross-border fund ${ }^{13}$.

P2P lending is providing unsecured loans through online web platform by matching lenders demands and investors supply. Portion of small amount ${ }^{14}$ can be collected in small fragments of loan required by borrowers and once it is enough to cover loan amount, loan is generated and provided to the borrowers. Interest rate varies between higher than savings rates and lower than market rates. Loan is returns on maturity/ paid earlier/ at default of borrowers. This type of lending is used for financing transactions such as real estate, venture capital, business-to-business, graduate, technological startups or eBay purchases etc. ${ }^{15}$ ECF provides investments options in the form of equity stake in business to many investors through online web platform ${ }^{16}$ serving as an intermediary between investors \& starts-up/SMEs.

Generally, funds are made available by Private Equity (PE), angel investors, Venture Capital Funds (VCFs) and financial institutions only after the business becomes commercially viable. But ECF solicits fund at the early stage. These early stage fund solicitations benefiting business to raise fund at low cost without following rigorous procedures to raise a capital and provides a much-needed increase credit flow. ECF

13 European Union. (2017). Executive Summary: Identifying market and regulatory obstacles to cross-border development of crowdfunding in the EU. Retrieved from: https://ec.europa.eu/info/publications/171216-crowdfunding-regulatoryobstacles-crossborder-development_en

14 FSA. (2012). Crowd-funding: is your investment protected?. Retrieved from: www.fsa.gov.uk/consumerinformation/ product_news/saving_investments/crowd-funding

15 Verstein, A. (2011). The misregulation of person-to-person lending. UCDL Rev.,45, 445.

16 Bradford, C. S. (2014). Shooting the Messenger: The Liability of Crowdfunding Intermediaries for the Fraud of Others. U. Cin. L. Rev., 83, 371. 
provides an option to investor to diversify its portfolio in the form of a new investment product avenue by increase competition among the traditional fund providers. These benefits do not come easily as investing \& financing Start-ups/SMEs are treated as an aggressive and long-term investments having high risk of liquidity. In ECF the investments solicitation is being done by small/retail investors in the form of small money which is otherwise taken by VCF/PEs investors. As retail investors are unsophisticated investors and not much informed hence tolerance level might be low and likely to act with a herd mentality and may not be in position to bear the loss of investments. ${ }^{17}$

In the case of default, they do not have any recourse to their investments. As fund is raise through internet there is a risk of cyber-security/identity theft and simply using social sites more investors can be influenced to invest who might be potentially affected by frauds. Lack of diversification principles, illiquidity, Cross-border implications, different jurisdiction laws in cross-border funding etc. are some of the systemic risk. There is a high chance of information asymmetry in the form of heavy reliance on soft information and lack of hard information, lack of control on incoming \& outgoing money, lack of transparency and reporting obligations etc.

\section{Comparative regulatory chart of selected countries on various crowd funding Models}

Following comparative chart is explaining the regulatory and supervisory convergence issues considered by various selected countries policymakers while bringing regulatory framework on crowdfunding.

Chart 1. Structure of Crowd-funding Regulations

\begin{tabular}{|c|c|c|}
\hline \multirow{2}{*}{ Country } & Inbound & Outbound \\
\hline & Company/ Project & Company/ Project \\
\hline \multirow[t]{7}{*}{ Germany } & $\begin{array}{lll}\text { Foreign Crowd funding Platform } & \text { FCFP to German } & \text { Company/ } \\
\text { (FCFP) to German Investors(GI) } & \text { Project (GCP) } & \end{array}$ & $\begin{array}{ll}\text { German Crowd funding (GCF) } & \text { GCF to FCP } \\
\text { to Foreign Investors (FI) } & 1 . \text { CFP }\end{array}$ \\
\hline & 1. Crowd funding Platform (CFP) & 2.FCP offering \\
\hline & 2.Foreign Company/ Project (FCP) & 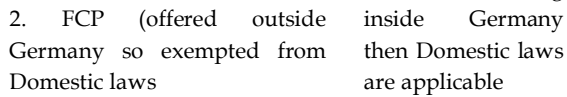 \\
\hline & Applicable Regulati & \\
\hline & $\begin{array}{l}\text { FCFP address GI in German language then following rules are } \\
\text { applicable- } \\
\text { If licensed } \mathrm{u} \text { / foreign MiFID / MiFID II license then allowed even without } \\
\text { present in Germany otherwise local license required } \mathrm{u} / \mathrm{S} \text {. } 32 \text { of Germany } \\
\text { Banking Act (GBA). Under Section } 34 \mathrm{f} \text { of German Trade, Commerce and } \\
\text { Industry Regulation Act (then German Regulations are applicable i.e. (GTC }\end{array}$ & $\begin{array}{l}\text { GCP addressing only FI- } \\
\text { Exempted since only FIs are addressed and only foreign } \\
\text { (e. g. French) language is used. GCP is offered to } \\
\text { foreigner so German Securities Prospectus Act (GSPA) } \\
\text { \& GIPA is not applicable. }\end{array}$ \\
\hline & $\begin{array}{l}\text { \& IRA), if the platform only conducts investment broking and only offers } \\
\text { profit-participating loans, subordinated loans/ or commercially } \\
\text { comparable investments publicly for the first time. FoCP will not be falling } \\
\text { under Act on Money Laundering (AML). }\end{array}$ & $\begin{array}{l}\text { GCP addressing FCFA- } \\
\text { Through German Language if GI is addressed then } \\
\text { German Regulations are applicable i.e. GTC \& IRA, } \\
\text { GBA, GIPA, GSPA. }\end{array}$ \\
\hline & $\begin{array}{l}\text { FCFP addressing FCP in Germany- } \\
\text { German prospectus regimes applicable if FCFP offers transferable } \\
\text { securities or all other Investment Products as per the German Investment } \\
\text { Products Act (GIPA). If FCFP are offering subordinated Profit participating } \\
\text { loans (since only these investment products) are exempted under } \\
\text { Crowdfunding exception. }\end{array}$ & \\
\hline
\end{tabular}

17 Alarm bells for crowdfunding as bubble pops for soap start-up. (2013, July 31). Financial Times. Retrieved from: http://www.ft.com/intl/cms/s/0/8d680fd4-f9d9-11e2-b8ef-00144feabdc0.html\#axzz3OgruYYXa 
Hasanuddin Law Rev. 5(1): 55-76

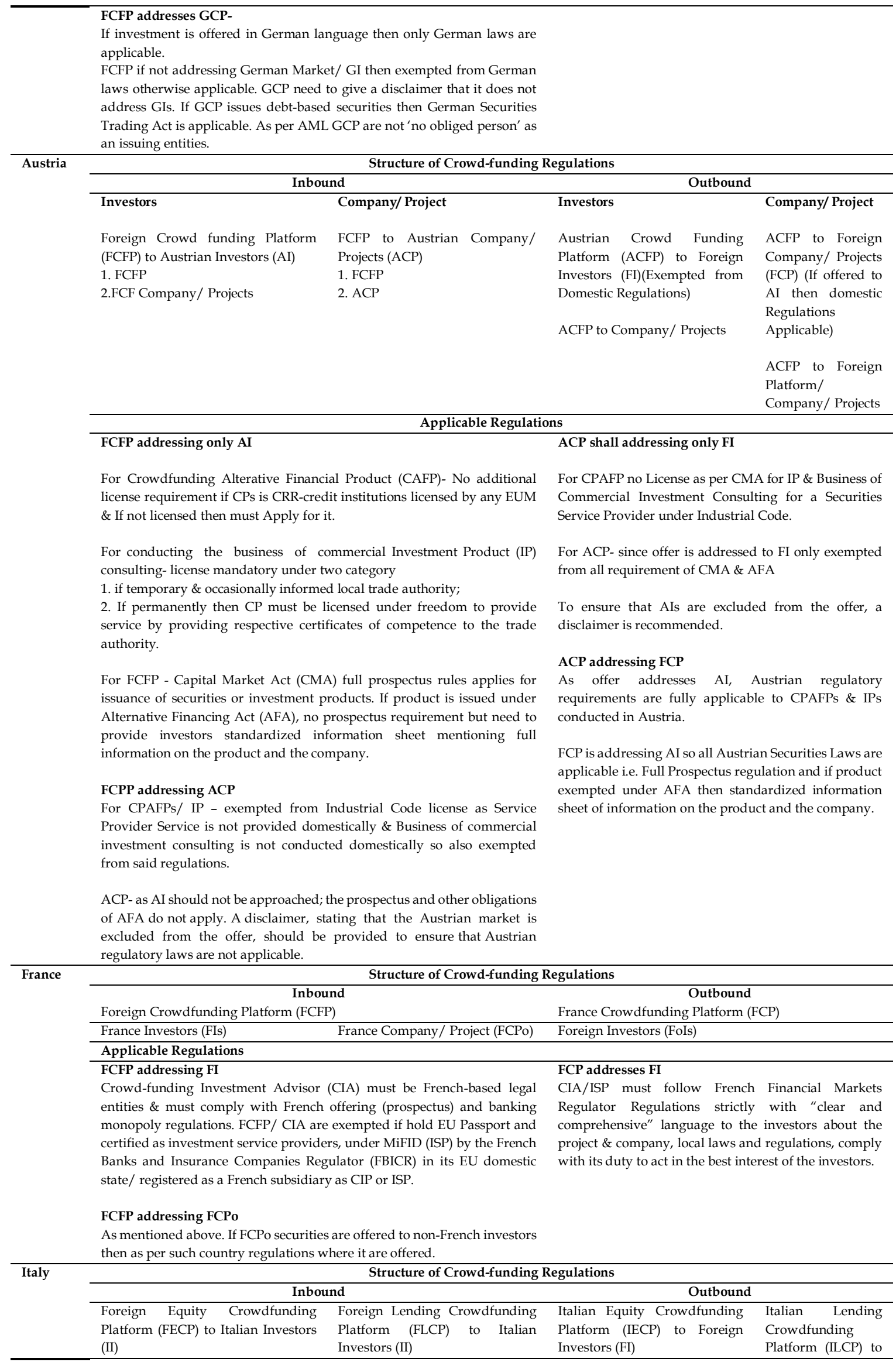




\begin{tabular}{|c|c|c|}
\hline & & $\begin{array}{l}\text { Foreign } \\
\text { (FI) }\end{array}$ \\
\hline & \multicolumn{2}{|l|}{ Applicable Regulations } \\
\hline & $\begin{array}{l}\text { FECP addressing II, FECP addressing Foreign Company/ Projects (FCP ) } \\
\text { to II \& FECP addressing Italian Company/ Project (ICP) - } \\
\text { If FECP is a MIFID EU license holder otherwise authorized by TUF \& } \\
\text { CONSOB license allowed doing business through the Establishment of a } \\
\text { local branch/ by Agent. Comply with relevant prospectus requirements } \\
\text { (and/or with the relevant exemptions).Same applicable to FECP } \\
\text { addressing to ICP. }\end{array}$ & $\begin{array}{l}\text { IECP addressing FIs, ICP and FCP- } \\
\text { Required to authorize by Italian Authority dealing with } \\
\text { Financial Markets (CONSOB) \& as per relevant EU } \\
\text { Country applicable laws and regulations where it want } \\
\text { to give service. Same laws apply to IECP addressing ICP } \\
\text { \& FCP. }\end{array}$ \\
\hline & $\begin{array}{l}\text { FLCP addressing to II, FLCP addressing FCP to II\&FLCP addressing ICP- } \\
\text { As per Italian Consolidated Law on Banking (ICLB) a Payment Institution } \\
\text { (PI)/- Electronic Money Issuer (EMI) authorized by EU Member state is } \\
\text { allowed to provide payment services by way of establishing local branch/ } \\
\text { online/ by Agent. FCP are allowed to publish a request for financing by } \\
\text { FLCP but must comply with all Italian Laws \& same shall be applicable for } \\
\text { FLCP addressing ICP. }\end{array}$ & $\begin{array}{l}\text { ILCP addressing FIs, ICP and FCP- } \\
\text { Only after authorized by CONSOB. As per EU Member } \\
\text { regulations in that country \& allowed to publish a } \\
\text { project in a EU Member but require following that } \\
\text { country Regulations and same for IECP addressing FCP } \\
\text { to inter-mediate }\end{array}$ \\
\hline \multirow[t]{6}{*}{ Sweden } & \multicolumn{2}{|c|}{ Structure of Crowd-funding Regulations } \\
\hline & Inbound & Outbound \\
\hline & $\begin{array}{ll}\begin{array}{l}\text { Foreign Crowdfunding Platform } \\
\text { (FCFP) to Sweden Investors (SIs) }\end{array} & \begin{array}{l}\text { Foreign Crowdfunding Platform } \\
\text { (FCFP) to Sweden Company/ }\end{array} \\
& \text { Projects (SCP) }\end{array}$ & $\begin{array}{l}\text { Sweden Crowdfunding Platform (SCFP) to Foreign } \\
\text { Investors (FIs) }\end{array}$ \\
\hline & Applicable Regulations & \\
\hline & $\begin{array}{l}\text { FCP addressing SIs \& SCP } \\
\text { For FCFP Equity -MiFID license \& EU Passport not required as per Swedish } \\
\text { law. For FCFP Lending- PSD-license is required along with EU Passport \& } \\
\text { must report to home country authority about cross-board activity. Can be } \\
\text { operated either through a branch, agent or entities to which the platform's } \\
\text { activities have been outsourced. Also Money Laundering and Terrorist } \\
\text { Financing (Prevention) Act (MLTFPA) \& if domicile of European Economic } \\
\text { Area Countries (EEA) then due diligence measures and ongoing follow-up } \\
\text { of business regulations expected otherwise applicable. }\end{array}$ & $\begin{array}{l}\text { SCFP addressing FIs } \\
\text { Activities in an EEA country Regulations \& must } \\
\text { informed S-FSA. If any change in condition of specified } \\
\text { in the company's conditions after the cross-border } \\
\text { activity has been initiated must notify to S-FSA \& must } \\
\text { comply with MLTFPA or EEA equivalent rules in this } \\
\text { regard. }\end{array}$ \\
\hline & $\begin{array}{l}\text { FCP addressing SCP } \\
\text { If non-transferrable securities are offered by company then no prospectus } \\
\text { requirement. Company Act applicable to Swedish Limited Liability } \\
\text { Companies (SLLC) thus FCFP are exempted from it. Information } \\
\text { compliance as per Marketing Practices Act (MPA). EEA fund seeking } \\
\text { companies/projects are exempted from MLTFPA compliance. }\end{array}$ & \\
\hline \multirow{5}{*}{$\begin{array}{l}\text { United } \\
\text { Kingdom } \\
\text { (UK) }\end{array}$} & \multicolumn{2}{|c|}{ Structure of Crowd-funding Regulations } \\
\hline & Inbound & Outbound \\
\hline & $\begin{array}{ll}\begin{array}{l}\text { Foreign Crowdfunding Platform } \\
\text { (FCFP) to UK Investors (UKIs) }\end{array} & \begin{array}{l}\text { Foreign Crowdfunding Platform } \\
\text { (FCFP) to UK Company/ Project } \\
\text { (UKCPs) }\end{array} \\
\end{array}$ & $\begin{array}{llll}\text { UK Crowdfunding } & \text { Platform } & \text { (UKCFP)to } & \text { Foreign } \\
\text { Investors (FIs) } & & & \end{array}$ \\
\hline & \multicolumn{2}{|c|}{ Applicable Regulations } \\
\hline & $\begin{array}{l}\text { FCFP addressing UKIs } \\
\text { If FCFP is authorized under MiFID- Passport rights then exempted from } \\
\text { obtaining authorization under UK Regulations, otherwise as per Financial } \\
\text { Services and Markets Act } 2000 \text { (FSMA) apply for authorized person } \\
\text { carrying FCFP services. } \\
\text { FCFP addressing UKCPs } \\
\text { Either fulfill or be exempted from Prospectus Condition of Company Law } \\
\text { of UK. If transferable securities then fulfill requirement of FSMA otherwise } \\
\text { it is criminal offence }\end{array}$ & $\begin{array}{l}\text { UKCFP addresses FIs } \\
\text { Exempted if fundraising activity \& offerings are for only } \\
\text { FIs, otherwise required to follow all UK regulations. } \\
\text { UKCFP must obtain license and Due Diligence } \\
\text { requirement, concerned regulations of host country } \\
\text { where it is doing business. }\end{array}$ \\
\hline \multirow{6}{*}{$\begin{array}{l}\text { United } \\
\text { States of } \\
\text { America } \\
\text { (USA) }\end{array}$} & \multicolumn{2}{|c|}{ Structure of Crowd-funding Regulations } \\
\hline & Inbound & Outbound \\
\hline & $\begin{array}{l}\text { 1. Any Foreigner/ US Platform initiate business services to foreign } \\
\text { Investors } \\
\text { 2. Title- II any Foreigner/ US to raise capital } \\
\text { 3. Title- III Only US to raise capital } \\
\text { 4. Title- III Only US/ Canadian to raise capital }\end{array}$ & $\begin{array}{ll}\text { Foreigner Platform must } & \text { No restriction on } \\
\text { registered in USA for accepting } & \text { USA entities to raise } \\
\text { USA investors in abroad } & \text { capital in abroad }\end{array}$ \\
\hline & \multicolumn{2}{|c|}{ Applicable Regulations } \\
\hline & $\begin{array}{l}\text { Anyone including foreigner can apply for Crowdfunding after an approval } \\
\text { from FINRA, the SEC and/or State regulators. } \\
\text { Not only JOBS Act but international regulations needs to be followed by CF } \\
\text { while offering and raising capital from foreign investors. }\end{array}$ & $\begin{array}{l}\text { American Crowdfunding Platform (ACFP) either with } \\
\text { proper registration or exemption from FINRA, the SEC } \\
\text { if US investor or AFC are involved. ACFF is raising } \\
\text { capital abroad then must follow host country regulation } \\
\text { in this regard. }\end{array}$ \\
\hline & $\begin{array}{l}\text { Under JOBS Act -Title-II allows anyone to raise capital, Title III allows US } \\
\text { to raise capital \& Title IV US \& Canadian may raise capital }\end{array}$ & \\
\hline
\end{tabular}

Source: Secondary data, 2019 (edited). 


\section{Application of Indian Legal Regime if any on Crowdfunding and Industry}

The raising of funds from public is heavily regulated in India. To raise a fund from public by Companies are governed by Company Act (CA) 2013, SEBI Act 1992, Securities Contracts (Regulation) (SCRA) Act 1956, Depository Act 1996 and lastly if pooled funds raised from public are managed by various entities in the form of Alternative Investment fund, Collective Investment Funds, Mutual Funds then said regulations of SEBI shall also have jurisdiction on it.

\subsection{The Companies Act (CA) 2013}

\subsubsection{Public Issuance (Securities) of Companies/ issuers}

As per the CA 2013 provisions, company raising of fund by public issue in the forms of securities need to comply with SEBI Regulations as well. Public issue need to comply Chapter III requirement in the form of prospectus ${ }^{18}$, listing agreement ${ }^{19}$ and application to get registered with recognized stock exchanges where shares are listed, traded and administered as per SEBI regulations ${ }^{20}$. The prospectus in the form of Red Herring Prospectus (RHP ${ }^{21}$ submitted to and approved by SEBI becomes the final prospectus that shall be submitted with the Registrar of Companies (RoC). The SEBI regulations among other is ICDR Regulations, 2009 for equity securities which includes information \& criteria to be adhered such as promoters' contributions \& lock-in requirements, merchant banker, registrar to issue, detail draft prospectus (offer document), detail disclosure like minimum eligibility criteria of track record, monitoring agency etc.

For issuance of the debt securities, companies need to follow and comply with SEBI (Issue and Listing of Debt Securities) Regulations, 2008 (ILDS). The requirements are credit rating from recognized credit rating agency, appointment of debenture trustee, detail disclosure requirement and Further continues listing requirements where securities are listed on recognized stock exchanges, etc.

\subsubsection{Private Placements (securities) of Companies / issuers}

CA 2013 has tightened the regulations on Private Placements Offer Letter (PPOL) due to recent misuse of PPOL route by some companies ${ }^{22}$ while issuing huge number of public debt securities. Therefore, CA 2013 has put some restrictions on private placements under Section 42 read with Companies (Prospectus and Allotment of Securities) Rules, 2014 made under Chapter III. The restrictions are, PPOL shall be made up to 200 persons in aggregate only in any financial year such limit is not applicable if PPOL is offered to QIB such as Mutual Fund, Foreign Portfolio Investor (FPI), AIF, Scheduled Commercial Bank, IRDA registered Insurance Company and Employees Stock Option Scheme as per SEBI (ICDR) Regulation 2009. Under form PAS-4, PPOL is made to those people's names that are recorded by issuer prior to the invitation to subscribe thus prohibited to release any public advertisements/media/ marketing/ distribution channels/ agents to inform

18 Company Act. 2013. Chapter III. Ss. 23 to 41.(Ind.)

19 SEBI (Listing Obligations and Disclosure Requirements) Regulations, 2015(Amended on February 15, 2017). Retrieved from: https://www.sebi.gov.in/legal/regulations/feb-2017/sebi-listing-obligations-and-disclosure-requirementsregulations-2015-last-amended-on-february-15-2017-_37269.html

20 SEBI (Issue of Capital and Disclosure Requirements) Regulations. 2009. Chapter XI.

21 Company Act. 2013. Section 32 .(Ind.)

22 Sahara India Real Estate Corporation Ltd. E Ors. v. Securities Exchange Board of India \& Anr, (2013), 1 SCC 1. 
the public at large about PPOL. PPOL shall accompanied by an application form serially numbered and personally identified persons ${ }^{23}$ prohibiting others to apply. The maximum investment per person is Rs. 20,000 of face value of the securities. The Complete detail information PPOL and records shall be submitted to the RoC within stipulated time. Subscription amount shall not be paid in cash but through Cheque/ Demand Draft/Online banking only and from the subscriber's bank account. These records shall be maintained by Company under form PAS- 5 and securities shall be allotted within sixty days from the date of receipt, else return the money to the investors under form PAS-3. Within 30 days of allotment of securities, company shall fill return under form PAS-6 with ROC comprising complete detail information with PAN \& Email IDs of security holders. Any default in these compliances shall result into treating PPOL is a public offer \& all provisions of it along with SCRA 1956 \& SEBI Act 1992 shall be applicable mutatis mutandis.

\subsection{Regulations on SME and Start-ups funding}

Small and Medium Enterprises (SME) has got a boost up for raising of a fund from SEBI through routes such as SME Segment of Exchanges, Institutional Trading Platform (ITP), Category I- SME Fund under AIF Regulations to list their securities on recognized stock exchanges in India.

A company whose Post-Issue Face Value Capital (PIFVC) is up to Rs. 10 crore is allowed to list only on SME platform. If company's PIFVC is minimum Rs. 10 crore and up to Rs. 25 crore then the listed issuer has option of getting listing to be migrate to SME exchange ${ }^{24}$ if it is approved by shareholder through passing special resolution. Company can migrate ${ }^{25}$ from SME exchange platform to main board of stock exchange if proposing to issue further capital results into PIFVC beyond Rs. 25 crore. When a Company is exceeding Rs. 25 crore rupees as a PIFVC than compulsorily listing on main board of stock exchanges subjected to the in-principle approval of a main board before issuance of such securities. SEBI has provided various relaxations under ICDR 2009 such as filing of draft offer submission directly to the exchanges, ${ }^{26}$ exemption of Regulation 26 eligibility criteria, minimum application value per application and prospective allottees are fifty, filing of half financial report (abridged annual report to investors) only and publishing it in newspaper provided it is displayed on Company \& Exchange website. SMEs need to ensure liquidity in the market and compulsory market making 27 for minimum three years from the date of listing.

23 Companies (Prospectus and Allotment of Securities) Rules, 2014. Retrieved from: http://www.mca.gov.in/Ministry/ pdf/NCARules_Chapter3.pdf

24 SEBI (Issue of Capital and Disclosure Requirements) Regulations. 2009. Chapter XB.

25 SEBI (Issue of Capital and Disclosure Requirements) Regulations. 2009. Regulation No. 106T (Ind.)

26 SEBI (Issue of Capital and Disclosure Requirements) Regulations. 2009. Regulation No. 106O (Ind.)

27 SEBI (Issue of Capital and Disclosure Requirements) Regulations. 2009. Regulation No. 106V (Ind.) 
Moreover, SEBI has allowed those companies who are not listed on recognized stock exchanges and get listed on ITP28 without involving IPO/ Private Placement procedural requirement ${ }^{29}$. ITP gives option to company to migrate on main board after three years ${ }^{30}$. Only institutional investors and HNIs are allowed to invest in ITP companies IPOs. ITP helps to get visibility in the form of initial impetus. Start-up companies get investment from AIF, VCFs which enhances liquidity \& allows flourishing. There are some restrictions also in placed such as companies shall mandatorily exist from the platform after ten years of listing, minimum requirement of paid-up capital is Rs. 25 crore, revenue of Rs. 300 crore and minimum market capitalization is Rs. 500 crore.

\subsection{Regulation on Alternative Investment Funds (AIFs)}

The objectives are to overcome from a regulatory gap where various types of players of AIFs industry were not registered with SEBI ${ }^{31}$ and to pave way for more investments in start-ups, SMEs etc. and also to create a mechanism that take cares of monitoring, risk management \& sustainability of activities of various funds in Indian share market industry. Thus, covering investment is taken place strictly as per investment policy resulting into investor benefits by all private investment vehicles raising money in India from Indian/ foreign investors. Those funds which are regulated by other regulators \& regulations are exempted from the ambit of said regulations ${ }^{32}$. There are three categories broadly cover following funds as (1.) Socially/ economically desirable funds which are sub-categorized as Venture Capital Funds (VCF) 33 , Angel Funds (AF), SME funds, Social venture funds (SVF) and infrastructure funds (IF) (2) Private equity/ debt funds ${ }^{34}$ (3) Hedge funds including investment in derivatives. ${ }^{35}$

The provisions for AIF investing in SVF, SME funds and VCF/AF are as follows. Those AIF primarily investing in \& satisfying norms of social performance \& their investors are agree to get muted returns are allowed to be registered as SVF with SEBI. The minimum investment is Rs. 1 crore and can accept minimum grants of Rs 25 lakhs from any person without accruing any profit/ gain to be given to the provider and strictly utilized such grant for SVF only. Investment funds which are primarily investing in companies listed/ getting listed on SME exchange or SME segment of exchanges can get registered as SME funds with SEBI. Minimum 75\% investable fund in any SMEs and may become an underwriter for unsubscribed portion of issue. ${ }^{36}$ Investor who are experienced and having knowledge of risk in angel investment and ready to invest in start-ups/early stage companies can register as VCF/AF with SEBI. To get the investment from VCF/AF as a genuine investment conditions are, Company need to

\footnotetext{
SEBI (Issue of Capital and Disclosure Requirements) Regulations. 2009. Chapter XC. (Ind.)

SEBI (Issue of Capital and Disclosure Requirements) Regulations. 2009. Regulation No. 106Z (Ind.)

SEBI (Issue of Capital and Disclosure Requirements) Regulations. 2009. Regulation No. 106ZE (Ind.)

SEBI (Venture Capital Funds) Regulations ("VCF Regulations"). 1996.

Mutual Funds, Collective Investment Schemes, Family Trusts, Employee Welfare trusts, Securitization trusts, any other funds regulated by other regulators, etc.

SEBI (Alternative Investment Funds) Regulations. 2012. Regulation 3(1)(4)(a) (Ind.)

SEBI (Alternative Investment Funds) Regulations. 2012. Regulation 3(1)(4)(b) (Ind.)

SEBI (Alternative Investment Funds) Regulations. 2012. Regulation 3(1)(4)(c) (Ind.)

36 SEBI (Issue of Capital and Disclosure Requirements) Regulations. 2009. Chapter XB.
} 
incorporate in India \&not more than 3 years old, maximum turnover of Rs. 25 Crore, is unlisted and is not holding/subsidiary Company of parent company group turnover minimum Rs. 300 Crore, and also must not have family connection with investors. The conditions for $\mathrm{AF}$ investment ${ }^{37}$ are minimum Rs. 50 lakhs to maximum Rs. 5 Crore, having minimum corpus of Rs. 10 Crore and each investor can invest in AF minimum Rs. 25 lakhs. Minimum sponsor/manager contribution in AF is $2.5 \%$ of the corpus/ Rs. 50 lakhs, whichever is lesser.

To sum up P2P lending is falling under RBI regulations ${ }^{38}$. Prospectus requirement, SEBI LODR, PPO letter, investor's number restrictions, promoter's lock-in etc. cannot be substitute and applicable on crowdfunding securities, players \& industry thus there is a need of new regulations to govern crowdfunding industry in India.

\section{Proposed Regulation on Crowdfunding in India}

\begin{tabular}{|c|c|c|c|c|}
\hline \multirow[t]{2}{*}{ India } & \multicolumn{4}{|c|}{ Proposed Structure of Crowd-funding Regulations } \\
\hline & \multicolumn{2}{|c|}{ Inbound } & \multicolumn{2}{|c|}{ Outbound } \\
\hline & Foreign Crowdfunding Platform & Crowdfunding & Crowdfunding & Crowdfunding \\
\hline & (FCFP) to Indian Investors (IIs) & Platform (FCFP) to Indian & Platform (ICFP) to Foreign & Platform (ICFP) to Foreign \\
\hline & 1. FCFP & Company/ Projects (ICP) & Investors (FIs) & Company/Projects (FCP) \\
\hline & 2. Foreign Company/Projects & 1. FCFP & 1. FCFP & 1. FCFP \\
\hline & $(\mathrm{FCP})$ & 2. Indian & 2. Foreign Company/ & 2. Foreign \\
\hline & $\begin{array}{l}\text { Crowdfunding Platform may } \\
\text { operate as Equity/debt/fund } \\
\text { based }\end{array}$ & $\begin{array}{l}\text { Projects (ICP) } \\
\text { Crowdfunding Platform } \\
\text { may operate as Equity/ } \\
\text { debt/fund based }\end{array}$ & $\begin{array}{l}\text { Projects }(\mathrm{FCP}) \text { offered } \\
\text { outside India is exempted } \\
\text { from Domestic Laws }\end{array}$ & $\begin{array}{l}\text { Projects (FCP) offered Inside } \\
\text { India then Domestic Laws } \\
\text { are applicable. }\end{array}$ \\
\hline
\end{tabular}

\subsection{Proposed Definitions}

Issuer- means Small \& Medium Enterprises (SMEs), Starts-ups including sole proprietorships.

Control or under Common Control- means the right to appoint majority of the directors or to control the management or policy decisions exercisable by a person or persons acting individually or in concert, directly or indirectly, including by virtue of their shareholding or management rights or shareholders agreements or voting agreements or in any other manner.

Equity Crowdfunding (ECF)- means a share or securities issued to the general public for raising of the capital of the company and do not enjoy any preferential rights with regard to repayment of capital and dividend but enjoy the right to control the affairs of the business and all the shareholders collectively are the owners of the company.

Debts Crowdfunding (DCF)- includes debenture stock, bonds or any other instrument of a company evidencing a debt, whether constituting a charge on the assets of the company or not.

37 SEBI (Alternative Investment Funds) Regulations.2012. Chapter III.

38 RBI. (2017). Master Directions - Non-Banking Financial Company - Peer to Peer Lending Platform (Reserve Bank) Directions, 2017 (Updated as on February 23, 2018).(Released ID:RBI/DNBR/2017-18/57 Master Direction DNBR (PD) 090/03.10.124/2017-18). Retrieved From: https://www.rbi.org.in/Scripts/NotificationUser.aspx?Id=11137 
AIF Crowdfunding (ACF) - A separate category of funds either as Class I or Class III entities from a maximum of 1,000 Eligible Investors under SEBI (Alternative Investment Funds) Regulations, 2012.

Crowdfunding Platform (CFP)- means a registered entity itself or though registered brokers acts as an intermediary in an offer or sale of securities transaction through a program or application accessible via the Internet or other similar electronic communication medium to the public and does not offer investment advice/ recommend, solicit to securities displayed in its website or portal, compensate any person for refereeing any investor to invest on its portal, hold \& manages investors funds / securities and engage in activities determined by SEBI.

Explanation-CFP may engage intermediary in back office or other administrative functions other than the platform specific activities aforementioned.

Associated Person of a CFP-means any partner, officer, director or manager of a CFP directly or indirectly controlling a CFP, or any employee of a funding portal, other than persons whose functions are solely clerical or ministerial.

Start-up - A start-up company means a private company or a one-person company incorporated under the Companies Act (CA), 2013 or a limited-liability partnership under Limited Liability Partnership Act 2008 or a partnership firm under the Partnership Act 1932 and recognized as a "start-up" in accordance with the notification issued by the Department of Industrial Policy and Promotion.

SMEs- Micro, Small \& Medium Enterprises registered as per Micro, Small \& Medium Enterprises Development (MSMED) Act, 2006.

Expert Committee of Platform (ECP)-means a Committee comprising of 10 experts as follows: four professional expert from startup \& ventures industry, three professional experts from capital marks \& banking industry, two external professional nominated by platform who are not on pay roll and Managing Director of platform.

\subsection{Eligibility of Investors}

Investors linked to corporate finance or venture capital firms or Private Equity (PE) or A separate category of funds either as Class I or Class III under Alternative Investment Funds Regulation and minimum individual investment limit shall be Rs. 25 lakhs, or registered Foreign Portfolio Investors as per SEBI (Foreign Portfolio Investors) Regulations or certified sophisticated investors or High Net-worth Individuals (HNIs) worth Rs. 2 Crores or Qualified Institutional Buyers (QIBs) as per SEBI ICDR 2009 or Companies having minimum net worth of Rs. 20 Crore.

Retail Investors- an individual's having a minimum Rs. 10 Lacs annual gross income provided that they are investing on advice given by either Investment Advisers or Portfolio managers are allowed to invest maximum Rs. 50,000 in an issue or maximum overall 10\% net worth amount in various issues through CFP. These individuals are also required to certify that they have filed at least last 3 financial years Income Tax return, 
they are fully aware the risk involved and will not cross aforementioned investment limits.

\subsection{Issuer Eligibility, Type of Securities and Conditions}

Recognized and eligible Start-ups and SMEs can be treated as issuer.

\subsubsection{Investment Limits on issuer}

The issuer may issue through only registered CFP any following types of securities for aggregate amount mentioned below in any financial year under this regulation. This limit is for raising capital through only by crowdfunding mechanism along with the previous sales made by its predecessor and exempting other means of raising money provided that it is regulated by other regulatory compliances in India.

\subsubsection{Issuance of ECF/ DCF}

Eligible entity can raise up to INR 100 million or approx. USD 1.66 million by issuing equity shares or debentures/debt securities to only "Eligible Investors" provided, no single investor or group of investors shall hold more than $20 \%$ stake in the Eligible Entity. Condition of number of investors limit mentioned under Section 42 of CA 2013 shall be exempted under this route provided issuer is not crossing the limit aforementioned. The issuer/entity raising DCF shall be exempted from treating DCF as a 'deposits' under CA 2013.

\subsubsection{AIF Crowd Fund (AIFCF)}

Issuer can solicit AIFCF online and the pooled money can be invested in ECF/DCF provided they complies the aforementioned restriction limit.

\subsubsection{Conditions on issuing ECF / DCF/AIFCF}

Issuer shall be issuing these securities only through single CFP registered with SEBI and in conformity with Section 42 \& rule 12(1) along with other SEBI Regulations ${ }^{39}$.

ECF-Private Placement Offer Letter (PPOL) in ECF shall contain a summarized required information sheet as specified in the FORM PAS-4, the promoters shall maintains a minimum of $5 \%$ stake for at least 3 years and investors shall have same rights of an equity shareholder as per CA 2013.

DCF- The PPOL in DCF shall contain a summarized term sheet as specified in FORM PAS-4, Comply with Companies debentures or bonds rules, appointment of debenture trustee holding on behalf of investors investments, create a Debenture Redemption Reserve (DRR) of $25 \%$ of the value of the debentures deposited with Bank and the debentures holders shall have same rights as per CA 2013.

AIFCF- funds of eligible investors registered with a recognized CFP will be collected online and pooled under the AIFCF, minimum investment limit shall be 25 lakhs instead of Rs. 1 crore as per SEBI (AIF) Regulations, 2012, displaying notice on CFP saying that

39 Companies (Prospectus and Allotment of Securities) Rules. 2014. Form PAS-4 prescribed under Section 42 and Rule 14(1) and SEBI (Issue and Listing of Debt Securities) Regulation. 2014. 
AIFCF is being set up by class I or III entities as per SEBI (AIF) Regulations, 2012. The sponsor or manager need to maintain continuing interest of at least $2.5 \%$ of the corpus exclusively without any waiver of management fees.

\subsubsection{General Conditions}

Would be like the company's directors, associates \& promoters are not disqualified to be appointed under CA 2013 or prohibited in accessing capital market or restrained in dealings/ trading in securities by any Courts or Competent authorities in India. They are not declared as a defaulter/ willful defaulter by RBI or CIBIL. They are declared by SEBI as 'fit and proper' persons ${ }^{40}$. Issuers are generally prohibited for direct/ indirect advertising/ solicit investments from the public.

\subsubsection{Disclosure Requirements \& Conditions}

The issuer shall submit PPOL to RoC and SEBI, and after approval, PPOL shall be provided to CFP and made available to potential investors. The disclosures includes the name, legal status, physical address and website address of the issuer, the names of the directors and officers, person holding more than $20 \%$ of the shares of the issuer, a description of the business and the anticipated business plan, material information which shall not be misleading/ false, number of employees appointed, risk factors, indebtedness, prior offerings \& failure if any, related-party transactions, description of the financial condition, the stated purpose and intended use of the target offering amount with deadline, regular updates on progress of meeting of the target offering amount; price \& method for determining the securities price, rights and liabilities attaching to the securities, details of the ownership and capital structure of the issuer; past history of funding \&prior refusal if any by CFP, Grievance Redressal and Dispute Resolution Mechanism. If there is oversubscription then maximum 25\% amount of actual issue size is allowed to retained, provided that over all issue amount size is not exceeding the limit aforementioned.

\subsubsection{Ongoing Reporting Requirements}

The issuer shall submit annual disclosures to the CFP. These disclosures include audited financial statements, utilization of funds raised, a detailed report of progress and current state of business, fund raised if any since last disclosure, any penalty, pending litigation or regulatory action against the company/ promoters/directors.

\subsubsection{Cross Border Issuers Accessing Indian Market}

The application of Indian laws in most cases depends whether there is a public offer according to the SEBI Rules \& Regulations, RBI rules and CA 2013. Therefore, Indian jurisdiction shall follow a market focused approach i.e. offer is as per aforementioned laws and to the Indian investors. It does not matter from where and from which country the offer is based, the CA 2013, RBI Rules \& SEBI Regulations shall also apply to foreign companies as Indian investors are involved. The main criteria for assessing whether there is a public offer or not is based upon the language used in the offer, the information of contact persons, approving agencies and tax rules. A disclaimer that informs the

40SEBI (Intermediaries) Regulations. 2008. Schedule II. 
investor that single markets (i.e. Indian) are excluded from the offer constitutes another indication that there is no public offer as per aforementioned regulations.

To sum up, it can be said, that Indian legislation may be applicable to various crossborder matters. Even though legislation is might be similar as in other countries, the clear guideline provides clear rules based on which it can be assessed if there is a public offer.

\subsection{Eligibility of CPF and Requirements}

\subsubsection{Eligible $\mathrm{CPF}$}

a. SEBI Recognized Depositories \& Stock Exchanges with nationwide terminal presence (RSEs).

b. Technology Business Incubators (TBIs) promoted by National Science \& Technology Entrepreneurship Development Board under Government of India- Department of Science \& Technology. Provided that TBIs are having at least 5 years of experience, and a minimum net worth of Rs. 10 Crores. Restriction on TBIs is that they shall display only those issuer's having a common focus thrust areas.

c. Following business model registered with SEBI and also following Indian Regulations are allowed to set up crowdfunding platform and doing operation in India.

i. A joint venture of a Class I entity and a Class III entity under SEBI AIF regulations, as a new class of AIFs Crowd Fund (AIFCF).

ii. Foreign Registered Crowdfunding Platforms (FRCFP) conducting their separate business in India.

iii. FRCFP conducting their operation via an Indian partner platform or through setting up Special Purpose Vehicles in India to collect investment from Indian investors for investing outside the India or within India.

iv. Platform mentioned in above three categories following Indian regulation to accept cross-border investments for predominantly local deal-flow.

$v$. The platform focuses on operating a brokering marketplace, accepting cross border investments under Indian rules while partnering with locally licensed or approved deal originators in the target Member States.

\subsubsection{General Requirements}

CFP must require adequate capital- technology- human resource which shall play a role of gatekeeper for reducing the systemic risk factors towards investors and also a cost effective facilitators to issuers. The obligations are as follows:

a. License and Registration- CFP shall apply for register with the SEBI and after scrutiny if SEBI found them eligible shall grant license to operate as a CFP. If CFP are acting as a broker or through broker then need to additionally comply with SEBI broker \& sub-broker regulation and other condition as SEBI deemed fit. Category I platform are exempted from the compliance requirement as they are already regulated under well-established SEBI Rules \& Regulations. 
b. Financial Interests- CFP including their promoter, directors and officers shall not have any financial interest in offerings/ issuer using its services and prohibited from investing in it. The CFP may receive maximum $5 \%$ of total amount as a compensation for service provided to issuers.

\subsubsection{Measures for reducing risk of fraud}

CFP shall have duty to do basic due diligence in the form of filtering and differentiation of qualitative ideas and business plans to reduce the risk through ECP. It is the duty of the CFP to cross verifies submitted report including background \& history of promoter, directors \& officers of issuer and person holding more than $20 \%$ stake in issuer. CFP shall proceed further only when it get positive report from ECP. CFP may reasonably rely on an issuer's record, compliance reports submitted unless otherwise it has reason to question on reliability of submitted report.

\subsubsection{Denial of Access by CPF}

$\mathrm{CPF}$ may deny access to issuer if ECF has given negative report in detail mentioning that ideas or business plan is not worthy or issuer is unable to access effectively the risk of fraud or become aware after grant of access to the issuer that there is potential for fraud/ issues with investor protection. CFP shall promptly remove the offering from its platform, cancel the offering and return to investors any funds they may have committed. CFP may charge nominal fee from issuer\& investors which shall be displayed on portal.

\subsubsection{Opening of Investors Account}

Platform shall be complying and accepting money as per Depository Act 1996 using the services of National Securities Depository Ltd (NSDL) \& Central Securities Depository Ltd (CSDL). Investor has to open an account with CFP. Notice of conditions for eligible investor shall made available on CFP and making sure that investors has submitted certificate of compliance of conditions on limits of amount to be invested in crowdfunding. CFP shall also make sure that investors are made aware of risk and get an acknowledgement of risk informed to and given to the investors.

\subsubsection{Information for investors on CFP}

CFP shall provide the information related to the process for the offer, purchase \& issuance of securities, risk associated with investment, voting rights if any with securities, annual reports of issuer, frequency of such report, restriction on resale of securities, minimum issue amount need to generated, circumstances where issuer may cancel issue, when investor can cancel investment commitment.

\subsubsection{Transactions Requirements}

a. Issuer Information: CFP shall make available to SEBI \& investors, all the details of issuers going for issuance of securities \& their types before 21 days to the actual day of issuance of securities. The details shall remain publicly available on the platform until the offer and sale of securities is completed or cancelled. The issue shall remain open for a maximum period of 15 days. 
b. SEBI Centralized Data Repository of Eligible Investor (CDREI): There shall be CDREI created by SEBI with the help of tax department. All eligible investor are required to register with CDREI where all conditions of investment and updated information of investment is stored. The information of investor will be automatically generated by CFP when investor gets registered. This will help CFP to keep check and make sure that the investors are eligible and well within aggregate amount limits that can be invested in crowdfunding during a 12-month period.

c. Communication Channels: CFP shall provide communication channels for registered investors only to communicate with each other \& with authorized persons of issuers those are allowed from issuer side to do communication and participate in discussion and answer to all the queries. The information shall be publicly available.

d. Order of Investment and Completion of Transaction/ Offerings: CFP shall provide investor unconditional right to cancel order without any reason until 48 hours of issuance of securities. Thereafter order cannot be cancelled. Once investor's acknowledgement of investment commitment is received, CFP shall promptly notify and discloses to investors about the types of securities, details of the issuer, date \& time of issuance of securities and date \& time by which investor may cancel order, number of securities sold \& allotted by issuer along with price, terms and rights on securities.

e. Issue can be closed prior to deadline provided that target offering amount is reached and offering was opened for a minimum 21 days. If target offering amount of issue did not reached or completed or issuer terminates the offering of issue, platform shall notify investors within 3 business days about reasons of such event, status of refund amount and prevent investors from investing in that issuer offering.

\subsubsection{Maintenance and Transmission of Funds}

CFP is prohibited to hold or transfer any fund of investor with itself. Platform shall comply with SEBI (Bankers to an Issue) Regulations, 1994 as far as maintenance/ transmission/ return of investor funds are concerned. CFP shall have contract with any registered Scheduled bank/ Provider that shall hold investor funds in escrow account for and transmit to issuer or return such funds directly to the owners entitled thereto in the event of contingency has occurred by order of CFP.

\subsubsection{Third Parties Services}

CFP may engaged with SEBI authorizes third parties only and compensate in lieu of general business services avail such as web search engine advertisement, banking services, depository participants (DP), Investment Advisers, Portfolio Managers etc. provided that payment is not made to the person who are in any manner indulged in purchase/ sale of securities offered by platform or issuer.

\subsubsection{Additional Funding Portal Requirements}

CFP shall need to fill up a crowdfunding platform form \& keep updated. The proposed form would require to give information such as organization structure, successions, person in control, non-securities related business, escrow account, arrangements of 
compensation \& withdrawal, Website URL/ location \& physical address, arrangements with recognized third parties, directors, officers, promoters \& their control relationship, portal is prohibited from advertising that offerings listed with it are safe and better than other portal \& highlighting any specific offerings, portal is allowed highlighting particulars based on objective criteria such as types of securities, issuer's geographic location \& industry segment, target amount \& progress of meeting of target amount, minimum \&maximum amount of investment which shall be equally applicable for all issuer using said CFP services and CFP is prohibited to do any discrimination in this regard.

\subsubsection{Requirements for Nonresident Funding Portals:}

Non-Residential Crowdfunding Portal (NRCP) shall be allowed in India provided that there is an information sharing arrangement in place with SEBI \& the competent authorities of country where the NRCP is situated and having its principle place of business. Apart from aforementioned requirement NRCP shall furnished information such as appointment letter of person in India and his details upon whom SEBI may serve any documents and provide access to NRCP books \& records for inspection \& examination as and when required and enforcing rules regarding activities of NRCP. NRCP shall publicly disclosure on their portal stating that it is a NRCP \& complying all the regulations of SEBI, language of portal, their home country registration detail information, written documents about any arrangement with local partner/platform, residential person representing foreign portal locally with his full name, address, email and appointment letter with remuneration, issuers detail information including country where it is located, amount, investor protection \& grievance redressal mechanism in that country, approval of regulators of that country got by issuers etc.

\subsubsection{Ongoing Compliances}

CFP shall comply with said policies and procedures, rules and regulations of SEBI which ever applicable under this regulation while doing its business, compliances with Anti Money Laundering Act/terrorist financing and other financial crimes, maintenance of all records and furnish all records as and when call by SEBI for inspections and examinations etc.

\subsection{Secondary Market}

Main object of crowdfunding is to raise capital online and not to resale of securities by Startups \& SMEs. Moreover, issuers are not following listing obligation \& treated as an Unlisted Companies. Thus, securities are not allowed to resale. In following circumstances investors are allowed to sale their securities: if issuer is buying back of securities as per CA 2013 (Buy Back by Unlisted Public Limited Company) Rules/investors registered with portal/Investor gets exit option where there is a sale or management buyout of the company/floatation of IPO or listing of company on SME segment/main board of recognized Stock Exchanges. 


\subsection{Tax Exemptions}

As per Start-up India Action Plan, ${ }^{41}$ start-up which are eligible under GSR Notification 501(E) are exempted under Sections 56 \& 80IAC from tax laws provided they submit prescribed document along with application. To get a tax benefits, Business eligible certificate is perquisite from Inter-Ministerial Board of Certification of Department of Industrial Policy and Promotion. Under S. 56 start-up can apply for exemption for Angel Tax provided that they are Private Limited Company or Limited Liability Partnership. It is proposed that the investor's average income should be more than Rs.15 lacs per annum instead of Rs. 25 lacs for last three years. Tax holiday shall be avail for initial three year out of seven year since incorporation provided that they are recognized in one of the form aforementioned \& incorporated after 1st April, 2016.

SMEs- Entity having annual turnover of maximum Rs. 50 Crore shall liable to pay tax $25 \%$ instead of earlier 30\% bracket, shall enjoying tax benefits such as $0 \%$ long-term capital gains tax and 15\% short-term gain tax on access to capital and equity finance, Minimum Alternate Tax (MAT) future liability has been expended to 15 year instead of 10 years. SMEs having maximum turnover of Rs. 2 crores shall enjoy reduction in presumptive tax by $2 \%$. GST benefits shall be there for a seamless flow of tax credits across India, need to file quarterly returns only if turnover is maximum Rs 1.5 crores. The business having multi-state operations \& turnover maximum to Rs. 20 lacks not required any GSTN registration. As far as CFP and investors are concerned they shall be tax as per present applicable tax provisions ${ }^{42}$.

\subsection{Deviations by Issuers/ CFP and Enforcement}

Any default/misrepresentation/ fraud/deviations by issuer shall be dealt under CA 2013 \& its rules \& regulations applicable to the private companies. The definition of fraud under CA 2013 shall be applicable mutatis mutandis to all the fraud or hiding any material information and be treated at par and with same provisions of existing civil and criminal laws which are applicable to the private companies. The RoC will have administrative jurisdiction and shall enforce all the provisions related to the private companies and special court shall have jurisdiction to hear any case coming out of this regulation. The issuer shall be debarred permanently in future to raise any money under crowdfunding regulation. Platform shall be dealt under the violation of SEBI Act, SCRA and Depository Act for deviation in compliance or any default. SEBI may take administrative action in the form of suspend or revoke a license, restraint licensee to participate in business, impose penalty, recovers money through penalties, conditional approval to do business, appoint SEBI Administrator as care taker, take appropriate recourse through court of law etc.

41 Ministry of Commerce and Industry (2017).Notification on constitution of Inter-ministerial Board under Department of Industrial Policy and Promotion.(Released ID: F.No. 5(91)/2015-BE.I) Retrieved from: https://up.startupindia.gov.in/content/sih/en/startupgov/startup-recognition-page.html

42 Ministry of Finance. (2017). Reduction/exemption of tax rates under GST for small businesses. (Released ID: 169401). Press Information Bureau, Government of India, Delhi. Retrieved from: http://pib.nic.in/newsite/mbErel.aspx?relid=169401 


\subsection{Exemptions and Amendments in existing Laws in India to boost-up Start-up and SMEs}

Start-ups need to self-certify compliance online on Shram Suvidha Portal and regulating the inspections for a period of 5 years 43 as allowed by Ministry of Labour \& Employment ${ }^{44}$ under nine labour laws ${ }^{45}$. Start-ups for the first year of setting up shall not be inspected on any receipt of credible and verifiable complaint of violation under any of the BoCW Act, ISMW Act, Gratuity Act, CLRA, EPF Act and ESI Act provided that written complaint is filed and has approval from superior authority or from Central Analysis and Intelligence Unit (CAIU) by the inspecting officer or Assistant Apprenticeship Adviser under the said Act ${ }^{46}$.Under Environmental Acts, certain startups are exempted from environment clearances.

Under Schedule 647 of Foreign Venture Capital Investors (FVCI)/NRI ${ }^{48}$ may contribute $100 \%$ of the Start-up company capital under the automatic route, with modification, provided they are not crossing there limit where startups is raising fund through any types of securities against receipt of foreign remittance (as per FEMA Regulation) under crowdfunding regulation. If a startup is having its overseas subsidiary earning out of exports/sales can open currency account with foreign bank for crediting to the account of startup or its overseas subsidiary and exports from India balances shall be repatriated to India for realization of exports of goods \& services ${ }^{4}$.

With the permission of RBI, startups can raise fund by Convertible Note i.e. debt money convertible into equity shares within five years of issuance on the happening of a specifics event as per the terms \& condition agreed by parties. With the modification instead of Rs. 25 lakh, foreigner can purchase this notes under crowdfunding route on the condition that an amount is not crossed under aforementioned regulation along with the entry route, sectorial caps and pricing guidelines.

43 The Inter-State Migrant Workmen (Regulation of Employment and Conditions of Service) Act, 1979.

44 Ministry of Labour and Employment. (2017). Advisory on increase in Self-Certification duration from 3 years to 5 years Startup India.. (Released ID: F.No. 5(91)/2015-BE.I) Retrieved from: https://shramsuvidha.gov.in/startUp.action

45 The Industrial Disputes Act 1947; The Trade Unions Act 1926; The Building and Other Construction Workers' (Regulation of Employment and Conditions of Service) Act 1996 ("BoCW Act"); The Industrial Employment (Standing Orders) Act 1946; The Inter-State Migrant Workmen (Regulation of Employment and Conditions of Service) Act 1979 ("ISMW Act"); The Payment of Gratuity Act 1972 ("Gratuity Act"); The Contract Labour (Regulation and Abolition) Act 1970 (“CLRA”); The Employees' Provident Funds and Miscellaneous Provisions Act 1952 ("EPF Act”); The Employees' State Insurance Act 1948 ("ESI Act”).

46 Ministry of Skill Development and Entrepreneurship. (2016). Notification on Incentivize startups engaging apprentices under the Apprentices Act 1961 read with the Apprenticeship Rules 1992 ("Apprentices Rules").

47 RBI. (2000). Notification No. FEMA 20/2000,Foreign Exchange Management (Transfer or Issue of security by a person resident outside India) Regulations, 2000. (Released ID: G.S.R.No.406(E) dated 08.05.2000) Retrieved from: https://rbi.org.in/Scripts/BS_FemaNotifications.aspx?Id=174

48 RBI. (2016). Foreign Exchange Management (Transfer or Issue of Security by a Person Resident outside India) (Third Amendment) Regulations, 2016.(Released ID: Notification No.FEMA.363/2016-RB). Retrieved from: https://rbi.org.in/Scripts/NotificationUser.aspx?Id=10386\&Mode $=0$

49 RBI. (2016). Foreign Exchange Management (Export of Goods and Services) Regulations, 2015. (Released ID: RBI/201516/395 A.P. (DIR Series) Circular No.68 [(1)/23(R)]). Retrieved from: https://rbidocs.rbi.org.in/rdocs/notification/PDFs/ APD6883071E462E56498C99FF8DDB9DD8A916.PDF 


\section{Conclusion}

Boom of Crowdfunding is posing an opportunity as well as challenges across the world regulators. Countries are giving different regulatory response to crowdfunding securities and business models adopted by crowdfunding platforms. To summarize there are basically two patterns that are emerging as a regulatory approach i.e. more restrictive regulations focusing challenges vs. mild touch regulations focusing opportunity. Countries such as US, Germany, Italy or France are following first approach and UK and New Zealand are following second approach. The proposed regulation has taken a market-based approach through developing bespoke enable regulatory framework on crowdfunding in India. Regulation is balancing the fostering of new funding sources to start-up \& SMEs, employment \& economic growth and on the other side, regulatory response to the non-tradable securities issuance to large retail investors and their protection. Present Regulation is mindful of cost-benefits to the issuers and its impact on raising of capital, competition in industry and efficiency of platforms. While granting certain exemptions from present securities and general laws, regulation is also putting restrictions through authorization, disclosure requirements and investment limitations on players in crowdfunding. The regulation is also trying to synchronize with other legislative regulatory overlap while granting exemption and wherever necessary bring in new appropriate mild regulation which is not overly regulated, complied by crowdfunding players in India. This move shall give a thrust to the economy growth by empowering start-ups \& SMEs to raise capital and uplifting the socio-ecosystem of India by generating scaled jobs to Indian youth.

\section{References}

Bradford, C.S. (2012). "Crowdfunding and the federal securities laws." Columbia Business Law Review, 1.

Bradford, C.S. (2014). "Shooting the Messenger: The Liability of Crowdfunding Intermediaries for the Fraud of Others," U. Cin. L. Rev., 83, 371.

Deschler, G. D. (2013). Wisdom of the intermediary crowd: what the proposed rules mean for ambitious crowdfunding intermediaries. Louis ULJ, 58, 1145.

European Union. (2017). Executive Summary: Identifying market and regulatory obstacles to cross-border development of crowdfunding in the EU. Retrieved from: https://ec.europa.eu/info/publications/171216-crowdfunding-regulatory-obstaclescrossborder-development_en

Fink, A. C. (2012). Protecting the crowd and raising capital through the crowdfund act. $U$. Det. Mercy L. Rev., 90, 1.

Kirby, E., \& Worner, S. (2014). Crowdfunding: An infant industry growing fast. IOSCO, Madrid.

Ministry of Commerce and Industry (2017). Notification on constitution of Inter-ministerial Board under Department of Industrial Policy and Promotion. (Released ID: F.No. 5(91)/2015-BE.I) 
Ministry of Finance. (2017). Reduction/exemption of tax rates under GST for small businesses. (Released ID: 169401). Press Information Bureau, Government of India, Delhi. Retrieved from: http:/ / pib.nic.in/newsite/mbErel.aspx?relid=169401

Ministry of Labour and Employment. (2017). Advisory on increase in Self-Certification duration from 3 years to 5 years Startup India. (Released ID: F.No. 5(91)/2015-BE.I) Retrieved from: https://shramsuvidha.gov.in/startUp.action

Ministry of Skill Development and Entrepreneurship. (2016). Notification on Incentivize startups engaging apprentices under the Apprentices Act 1961 read with the Apprenticeship Rules 1992 ("Apprentices Rules").

Mutual Funds, Collective Investment Schemes, Family Trusts, Employee Welfare trusts, Securitization trusts, any other funds regulated by other regulators, etc.

RBI. (2015). Master Circular on Basel III Capital Regulations (Press Release: RBI/2015-16/58

RBI. (2016). Foreign Exchange Management (Export of Goods and Services) Regulations, 2015. (Released ID: RBI/2015-16/395 A.P. (DIR Series) Circular No.68 [(1)/23(R)]).

RBI. (2016). Foreign Exchange Management (Transfer or Issue of Security by a Person Resident outside India) (Third Amendment) Regulations, 2016. (Released ID: Notification No.FEMA.363/2016-RB).

RBI. (2017). Master Directions - Non-Banking Financial Company - Peer to Peer Lending Platform (Reserve Bank) Directions, 2017 (Updated as on February 23, 2018).(Released ID: RBI/DNBR/2017-18/57

RBI. (2017). Report on Report on Trend and Progress of Banking in India 2016-17. Retrieved form: https://www.rbi.org.in/scripts/PublicationsView.aspx?id=18061

Sahara India Real Estate Corporation Ltd. E Ors. v. Securities Exchange Board of India $\mathcal{E}$ Anr, (2013), 1 SCC 1.

SEBI (Alternative Investment Funds Regulations) 2012. Retrieved from: https://www.sebi.gov.in/sebi_data/commondocs/AIFregulations2012_p.pdf

SEBI (Framework for recognition and supervision of stock exchanges / platforms of stock exchanges for small and medium enterprises) 2008. Retrieved from: http:/ / www.smelisting.net/SEBI/SEBI-framework-for-sme-platform.pdf

SEBI (Listing of Specified Securities on Institutional Trading Platform) Regulations, 2013 Retrieved from: $h$ ttps://www.sebi.gov.in/sebi_data/attachdocs/1381311146097.pdf

SEBI. 2014 Consultation Paper on Crowdfunding in India. Retrieved from: https://www.sebi.gov.in/sebi_data/attachdocs/1403005615257.pdf

Smith, S. E. (2014). Comments: The Securities and Exchange Commission's Proposed Regulations under the CROWDFUND Act Strike a Necessary Balance between the Burden of Disclosure Placed on Issuers of Securities and Meaningful Protection for Unsophisticated Investors. University of Baltimore Law Review, 44(1), 6.

The Inter-State Migrant Workmen (Regulation of Employment and Conditions of Service) Act, 1979. 
Tomczak, A., \& Brem, A. (2013). A conceptualized investment model of crowdfunding. Venture Capital, 15(4), 335-359.

Verstein, A. (2011). The misregulation of person-to-person lending. UCDL Rev., 45, 445.

World Bank. (2013). Crowdfunding's Potential for the Developing World. Retrieved from: https://www.infodev.org/infodev-files/wb_crowdfundingreport-v12.pdf

\section{Conflict of Interest Statement:}

The author(s) declares that the research was conducted in the absence of any commercial or financial relationships that could be construed as a potential conflict of interest.

Copyright (C) 2019 HALREV. All rights reserved. 